\title{
Paradox of Oil Wealth in the Niger-Delta Region of Nigeria: How Sustainable is it for National Development?
}

\author{
Imobighe M. D. \\ Department of Economics, Delta State University, Abraka \\ Tel: 08-03-600-6716 E-mail: imomondon2010@yahoo.com
}

Received: August 26, 2011

Accepted: September 28, $2011 \quad$ Published: December 1, 2011

doi:10.5539/jsd.v4n6p160

URL: http://dx.doi.org/10.5539/jsd.v4n6p160

\begin{abstract}
This paper draws attention to the paradox of oil wealth in the Niger Delta. It is noted that the area produces the largest proportion of the Nation's foreign exchange; there is no much of the transformational effects generated by the oil in these areas. The region has been saddled with environmental pollution originating from seismic surveys, canalization, poor waste disposal, oil spillage and gas flaring, with serious damage to aquatic life, agriculture and human health. The resultant effect is extreme poverty without the provision of basic infrastructure. The paper concludes that host communities should be seen as co-partners with government as in the production of oil and proceeds from it so as to create a conducive and enabling environment. The government is also encouraged to alter the unfair measure allocation formula to favor the oil producing states. Through this, rural urban poverty will be alleviated if basic human rights to life, liberty and property are guaranteed.
\end{abstract}

Keywords: Paradox of oil wealth, Poverty, Niger Delta, Sustainable, Development

\section{Introduction}

The greatest problem of our time along with environmental threats is rural/urban poverty. Poverty in its entire ramification is the lack of social and economic resources. Poverty according to Abdalah and Englehead (1933) observed ratio between the incomes of the richest $20 \%$ of the population of the world and that of the poorest $20 \%$ went from 30 to 1 in 1960 to 59 to 1 in 1989. In accessing the world of poverty, the World Bank in its report of 1990 estimated as follows:

There were 49 really poor countries in the world with an annual average income per head of less than $(\$ 350)$ three hundred and fifty United State dollars. 330 million urban residents or a quarter of the urban population were living in poverty.

- 800 million people in the developing countries went hungry and there were 100 million homeless.

- 1,116 million people in the third world countries were poor.

- Nearly half of all deaths were child deaths because half of this population was absolutely poor.

- Over 1.7 billion women lacked safe water; about 300 million did not have adequate sanitation, while 900 million could not read or write.

Based on per capita household expenditure, 71 percent of Nigerians were classified as poor, out of which $36 \%$ were classified as core poor and about 35\% moderately poor. Federal office of statistics (1995).

Todaro (1995) opined that "on the average, we may conclude that about 75 to 80 percent of all target poverty groups are located in the rural areas of Africa and Asia and about 70\% in Latin America". He went further to state that; "it is interesting to note in the light of the rural concentration of absolute poverty that the largest share of most LDC government expenditure over the past two decades has been directed towards the urban area and within the area, towards the relatively affluent modern manufacturing and commercial sectors". Whether in the realm of directly productive economic investments or in the fields of education, health, housing and other social services, this urban modern sector bias in government expenditures as the core of many of the development in these communities.

In Nigeria, a study by Onibokun, A. G. and Faniran, A. (1996), revealed that the proportion of household living below the poverty line in the four cities of Lagos, Ibadan, Kano and Onitsha were 63.7\%, 62.1\%, 35.02\% and 8.7\% respectively. 
However, despite the pervasive physical and social transformation of our national scenery enhanced by our oil resources, cry of desert and allegations of utter neglect by the people inhabiting the areas (Niger Delta) in which this national wealth is extracted have remained persistent. They have continued to lay the causes of their tribulations at the doorsteps of the oil companies who are accused of carting away their natural heritage with daring to give much in return. They also throw-in allegation that government has used the revenue to develop other parts of the country at their own expense, while the unending exploration of oil in their backyards has resulted in total destruction of the environment leading to the despoliation of flora and fauna and contamination of agricultural and water resources. Agitation for these infrastructural needs often results to breakdown of law and order, insecurity, tension violence, seizure of equipment, sabotage and hostage taking. The aim of this paper, therefore, is to examine and critically access the provision of basic infrastructure as a way of alleviating poverty in rural areas of the Niger Delta (N. D.).

This paper is organized into five sections. The first part shield light on the concept of "poverty" and its classification. The second aspect focused on the conceptual issues and theoretical framework of rural poverty in developing countries such as Nigeria. The third part addresses the causes of poverty in oil producing states and the need to provide basic infrastructural facility in the oil producing communities, while the fourth section examines the implications of rural/urban poverty for sustainable development in Nigeria. Section five concludes the write up.

\section{Conceptual Issues and Theoretical Framework of Rural Poverty}

Generally, there is no widely acceptable definition of poverty. This is as a result of different opinions held by different scholars. For instance, in economics, poverty has been defined by developing a poverty line using the minimum wage/income concept like that developed by Morgan Commission in Nigeria. Any group of people within the income brackets below the wage/income ratio is living below the poverty line. According to Townsend (1991) defined poverty as the lack of material resources of certain duration and to such an extent that participation in normal activities and possession of amenities and living conditions become impossible or very limited.

A more comprehensive definition of poverty is that given by Prado and Tobi (1994). To them poverty is a multi-dimensional phenomenon with few commonly agreed definitions across the characteristics of the poor, particularly the urban poor such as excessive labor flow, undifferentiated/unskilled persons who cannot readily be integrated into the production system, sub-culture of personalized ethical code in contrast to the norm of kindred or community behavior, scarcity of essential commodities (food, housing, clothing), growth of slums, unemployment and under-employment and crimes or deviant behaviors. Onibokun (2005) perceived poverty as living in sub-standard and sub-human environments plague by slums, squalor and grossly inadequate social amenities like health facilities, schools, recreational opportunities etc.

Gaibrath (1968) also diagnosed poverty as having limited people living in crowded and insufficient food and clothing, peoples living in crowded, cold and dirty shelters and people living painful and comparatively brief lives. Aluko (1975) presented a pragmatic and materialistic concept of poverty by giving it as an inadequate level of consumption giving rise to insufficient food, clothing and or shelter. Similarly, Olowu and Akinola (1995) pointed out that poverty is characterized by the lack of or inadequate access to infrastructures among others, while the rural/urban can easily be identified from the types of food they eat and the environment in which they live. According to World Bank (1994) as cited in Anyanwu (1997), infrastructure is an umbrella term for many activities referred to as "social overhead capital" and characterized by peculiar technical features (such as economies of scale) and economic features (such as spill-over from users to non-users). These include services from power, pipe water supply, telecommunications, sanitation and solid waste collection and disposal, roads, urban transports, port and waterways.

World Bank (1995) believe that the adequacy of the measure of one country's success is another's failure, especially in diversifying production, expanding trade, coping with population growth, reducing poverty, or improving environmental conditions. An adequate infrastructural provision in an environment is one key factor of attraction to investors. This is because it boosts productivity and enhances drastic production costs. This will have a multiplier effect of producing employment, increase income thus, welfare of the people and making them to be much more constructive rather than destructive as in the case in some part of the oil producing area of the country especially the Niger Delta. More so, it will improve welfare and standard of living and enhances environmental sustainability.

Summarily, poverty is defined as a way of life characterized by low calorie intake, inaccessibility to adequate health care facilities, low quality of educational system, low life expectancy, infant mortality, low income, 
unemployment and under-employment and inaccessibility to various housing and societal facilities (Imobighe, 2008).

\section{Causes of Poverty and Provision of Amenities in Oil Producing Rural Areas}

The yardstick for measuring poverty varies from one individual to another, which relegates the concept to a relative term. Fundamentally, two levels of poverty are easily discernible, that is, absolute poverty and relative deprivation. The two concepts are here treated holistically. Both economic and political developments of local, region, national and international levels have led to structures that often prevent the strata of society from taking part in the general process of development.

The Niger Delta has nearly 200 oil fields with well over 400 oil production and storage facilities scattered within its swamps and creeks, which are operated by multi-national firms such as Shell, Mobil, Chevron, Elf, Agip and Texaco in Joint venture with the Nigerian National Petroleum Company (NNPC). The Niger Delta is the main source of Nigeria's wealth. Well over 90 percent of Nigeria's export and foreign exchange earnings come from oil export and over 70 percent of total federally collected revenue originated from the oil sector Okoh and Egbon (1999).

The "unwarranted" poverty in rural areas of the oil producing states can be trace to the high activity level in the Niger Delta which has exposed the area to the dangers of water, land and air pollution as well as oil spills which harm aquatic life as well as the entire ecosystem, topography and surface vegetation. For instance, in 1979, a storage facility at the West Niger Delta, Shell-operated Forcados terminal collapsed. This spilled an estimated 560,000 barrels into surrounding land, mangrove swamps and the Atlantic. In 1980, another major blowout occurred which spewed out some 200,000 barrels of crude oil into the Atlantic and destroyed nearly over 840 acres of Niger Delta mangrove. In 1998, a 24 inch crude oil pipeline linking the Idoho offshore platform with the Mobil operated Qua Ibeo terminal ruptured. An estimated 40,000 barrels of crude spilled into Atlantic, polluting the coastline from Eket to Lagos and beyond the Nigerian Western boarder to Ghanaian sores, over 960km away Eromosele (1998). The Jesse fire incidence of 1998 is a recent happening where over 1,500 lives were lost and several hectares of farmland and plantations were razed by fire.

The impact of these mishaps has been grievous on the inhabitants of the Niger Deltas. One of the serious problems confronting the communities is that of destruction or damage to the ecosystem, topography and surface vegetation especially in the rainforest and mangrove areas. There is also the problem of deforestation, leading to loss of bio-diversity Okoroji and Okoro (1998) in the mangrove swamps. This has led to the destruction of nurseries and feeding grounds for many commercially important species of fishes and crusta crabs.

Also, the contamination of water bodies by oil has led to contamination of fisheries, fresh water and brackish water swamps and killing of fishes, crabs, co-systems and periwinkles. This has, therefore, rendered fishing (the main occupation in riverine areas) difficult. There is also the case of contamination of rivers and inland water which are important source of drinking water and food, thereby rendering such water and food unfit for human consumption.

The activities of the oil industry have also affected the health of the people of the Niger Delta environment. For instance, Ndlfon (1998) has identified oil acme (a special skin eruption due to exposure to oil) among residents. He also reports the incidence of cancer, disease fertility, fever, cough, abdominal pain and diarrhea. As much as 85 percent of his respondents suffered a combination of these symptoms. Major environmental problem leading to poverty in the Niger Delta are summarized in table 1 below.

As serious as the situation in the Niger Delta is, the Federal Government and the Multinational Corporations involved in the exploration and production of oil in the area seem not to have done enough to ameliorate the plight of the inhabitants of the area. The primary aim of government has continued to center on how to expand oil production and earn more revenue.

The host communities' watch as their God-given wealth from their backyard is taken away for the enrichment of others. And while they can no longer practice their major occupation of fishing, farming has become almost impossible. Their youths find it hard to gain admission into higher institutions and those who manage to get in cannot find ready employment because of quota restrictions Okoh and Egbon (1999).

The difficult Niger Delta terrain makes road construction and maintenance an expensive business. The area has thus, been denied the much-expected development of social and economic infrastructure such as electricity, roads, pipe-borne water etc. Also, rather than receive more funds for development, the revenue allocation to the area through the derivation principle has drastically reduced. Another factor which has not favored the provision of basic infrastructure is the derivation formula. Various commissions were set up by the colonial between 1951 
and 1961 such as Hicks-Philips Commission, the Raisman Commission, 1958, Binus Commission 1964, which recommended that 50 percent of the oil revenue should be allocated to the areas generating the resource. But in Decree 13 of 1970, and Decree 9 of 1971, derivation was pegged at 45 percent, leaving the total control of all offshore oil revenue in the hands of the federal government Onosode (1999). Worse of it all, as the oil revenue increases, the derivation principle became so de-emphasized. For instance, Decree No. 6 of 1975 further reduced derivation to 20 percent. The Abayode Commission of 1977 and the Okigbo Commission of 1980 eliminated derivation totally while in 1981, a recommended 2 percent for derivation and 1.5 percent for development of mineral producing areas. The Danjuma Commission of 1989, while maintaining 2 percent for derivation replaced the 1.5 percent development fund for oil producing areas with 2 percent revenue for development of non-oil mineral producing areas. By 1990, the Armed Forces Ruling Council (AFRC) approved a further decrease in derivation to 1 percent and 1.5 percent for development of oil producing areas. Agitations from the oil mineral producing communities led to the establishment of Oil Mineral Producing Areas Development Commission (OMPADEC) in 1992 with 1 percent for derivation and 3 percent for development of mineral producing areas Anyanwu (1995). OMPADEC performed below expectation; leaving only a legacy of abandoned projects and unpaid contracts all over the Niger Delta. The 1995 constitutional conference recommended 13 percent for derivation and development of oil producing communities. This recommendation has yet been implemented. The percentage allocated to derivation remained at 1 percent of oil revenue in 1999, despite General Abubakar's premises to develop the area shortly after assumption of office in 1998 Okoh and Egbon (1999).

A careful look at Table 2 would show the first seven states in descending order of the statutory allocation received by states. Kano (N3066.4 million), Sokoto (N976.8m), F. C. T. Abuja (N907.7m), Lagos (N904.9m), Bauchi (N891.6m), Borno (N878.9m) and Oyo (N869.4m). Rivers State took the eighth position with (N848.6m). The population column of table 4 shows that the states with the three largest populations are Lagos (5685.8), Kano (5632.0), Sokoto (4392.4). this shows the centrality of the population criterion as against the derivation principle in the revenue allocation formula.

Table 3 presents a comprehensive data in rural unemployment rate by all Nigerians and States. Cross-River (an oil producing state) recorded the highest unemployment rate of 14.9 percent in 1993, 7.0 percent in 1994 and 10.9 percent in June 1995. Rivers State (an oil producing area) topped the list with 15.2 percent in 199313.2 percent in 1994, 14.5 percent in $1995 \mathrm{Edo} /$ Delta also had a high rural unemployment rate (10.4 percent) in December 1993, 8.1 percent in September 1994. All these show that the pace of development is slow in the Niger Delta and cannot be a piecemeal affair or a project of selective isolation of communities. There is therefore, the need for the provision of basic infrastructure to cater for the high rate of unemployment in the area.

\section{The Implications of Rural/Urban Poverty for Sustainable Development in the Niger Delta}

Rural sustainable development implies the kind of development now, which does not permit future generations from developing themselves as a result of the weighed constraints on them. This is to say the alleviation of poverty in the rural and urban areas would not be achieved and the expected contribution of rural communities to sustainable development would be restricted due to the continuing pollution, environment degradation and others consequently, rural poverty contributes to unsustainable development since environmental degradation is prevalent in the rural poor areas as a multiple result of overstretched environmental facilities such as roads, public health care, sanitation and municipal services. However, in Nigeria until 1996, when the federal government set up Productivity, Price and Income Board (PPIB) to provide guidelines on the income wages, salaries, profits, dividends and rents, there was no income policy. Many of the past programmes of government particularly during the oil era gave priority attention to expensive projects with social reliance and are located in the non-oil producing areas while the rural poor provide the food stuff to urban centers with poor transport facilities.

The informal sector which employs the vast majority of the urban people is usually attended by low productivity and low income. For instance, the World Bank Nigeria participation poverty assessment exercise covering 37 urban or petty-urban and 58 rural communities in forty five local governments of ten states shows the general situation of poverty in Nigeria. Table 4 below shows that after rising steadily from N1350 in 1971 to N2900 in 1980, the real percentage capita income fell to N1200 in 1988. It then rose marginally but has since fluctuated between N1400 and N1500.

\section{Conclusion}

Poverty is the inability to attain a minimal standard of living. Its multifarious dimension includes inadequate incomes, malnutrition lack of access to social services, lack of social and political status. 
Undoubtedly, the Niger Delta is the major source of Nigeria's wealth, accounting for over 90 percent of Nigeria's export and foreign exchange earnings and over 70 percent of total federally collected revenue. Yet, the Niger Delta is saddled with a destroyed co-system, topography and surface vegetation. The problems above set the stage for poverty and underdevelopment of the Niger Delta area.

The host communities should be part owners with the federal government of the oil and proceeds from it. This would minimize the crisis rate and act of sabotage, which are now common to the area. The government must alter the unfair revenue allocation formula in favor of the oil producing communities to an acceptable equal rationality. The people of the Niger Delta should be given a fair deal by ensuring true representation as well as allowing them to play key roles in the revenue allocation decision making. A lot more is achieved if the poor are not only involved in the intervention programmes but also made to identify their problems and seek solution themselves. This is the challenge to rural poverty in the process of nation building in developing countries. Rural/urban poverty is alleviated when each of the following conditions is seen as a right to every inhabitant: Adequate water and sanitation facilities, adequate food, stable and healthy environment, affordable transport, gainful employment, basic health services, basic literacy, basic human rights to life, liberty and property.

\section{References}

Abdalah, T. B. \& Englehead. (1933). The Urgency of Fighting Poverty for Democracy and the Environment. United Nations Non-Governmental Liaison office, occasional paper.

Aluko, S. (1975). Poverty and its Remedies. Annual Conference of the Nigerian Economic Society.

Anyanwu, J. C. (1997). Structure of the Nigerian Economy. Revenue allocation and stable fiscal federation in Nigeria in: Journal of Economic Management, 2 (2), 1-28.

Eromosole, V. (1998). Costing Niger Delta's oil spills. The proceedings of the International Seminar on the Petroleum Industry and Nigerian Environment (pp. 360-365). Abuja.

Galbraith, J. K. (1968). This Affluent Society N. 4. Federal Office of Statistics (various years) family in the culture of poverty. London: Becka and Warburg.

Ikein, A. (1996). The impact of oil on a developing country. Ibadan: Evans Buther.

Imobighe, M. D. (2008). Environmental Pollution and Human Capital Development. International Journal of Research in National Development. 6 (2), 95-100.

Lolwu, Dele \& Akinoola, S. R. (1995). Urban Governance and Urban Poverty in Nigeria' in Onibokun, A.G. and Faniran (eds), Governance and Urban Poverty in Anglophone West, Africa, CASSAD Monograph series 4.

Maduka, W. O. (1998). Evolving vibrant communities for development and steady growth. The Proceedings of the International Seminar on the Petroleum Industry and the Nigerian Environment (pp. 867-882). Abuja P.

Ndifon, W. O. (1998). Health Impact of a Major Oil Spill. Case study of the Mobil Spill in Akwa-Ibom State Nigeria. The Proceedings of the International Seminar on the Petroleum Industry and the Nigerian Environment (pp. 804-813). Abuja.

Okoh, R. N. \& Egbon, P. C. (1999). Fiscal Federation and Revenue Allocation. Selected Papers Presented at the 1999 Annual Conference of the Nigerian Economic Society (pp. 405-419).

Okoroji \& Okoro (1998). Environmental quality. A challenge to the oil industry. The Proceedings of the International Seminar on the Petroleum Industry and the Nigeria Environment (pp. 655-685). Abuja, P.

Onibokun, A. G. \& Faniran, A. (Eds). (2005). Government and Urban Poverty in Anglophone West Africa. Monograph series 4. (1996) Urban and Housing indicators in Nigeria, UNDP Technical Report.

Onosode, G. (1998). Environmental and Community Considerations in Nigeria's Oil and gas Industry: Towards a reassessment. Proceedings of the International Seminar on the Petroleum Industry and the Nigerian Environment, Abuja. 853-8865. (1999). 40 years of oil and gas in Nigeria. In: The Vanguard. Monday, January 4, P. 26.

Prado, R. \& Tobi, D. (1994). Notes on Poverty Focus in Country Programming. The UNICEF workshop on urban poor and CEDC/II TA. (May 3-4, 1994).

Todaro, M. I. P. (1995). Economics for a Developing World. England: Longman Group Ltd.

Town Send, P. (1992). The Meaning of Poverty. The British Journal of Sociology, 12 (1).

Vanguard October 21, (1998). 
World Bank Report, (1994).

World Bank Report, (1996). Findings: Africa Region No. 62. (May, 1996).

World Bank Report, (1996). Nigerians Poverty Assessment Report No. 14733-UNI.

Table 1. Ranking environmental problems, social issues and priorities

\begin{tabular}{|c|c|c|}
\hline Problem Types & Problem Subject & Priority Ranking \\
\hline Natural Environment & $\begin{array}{c}\text { Coastal/river bank erosion } \\
\text { Flooding } \\
\text { Sedimentation/slit } \\
\text { Substance } \\
\text { Exotic (water-hyacinth) }\end{array}$ & $\begin{array}{c}\text { Moderately } \\
\text { High } \\
\text { Moderate } \\
\text { Low } \\
\text { Low } \\
\text { High }\end{array}$ \\
\hline Development Related & Land degradation/soil fertility loss & High \\
\hline & $\begin{array}{l}\text { Agric. decline/shortened } \\
\text { fallow } \\
\text { Delta forest loss } \\
\text { (mangroves) } \\
\text { Bio-diversity depletion } \\
\text { Fisheries decline } \\
\text { Oil spillage } \\
\text { Gas flaring } \\
\text { Sewage and waste water } \\
\text { Other chemicals }\end{array}$ & $\begin{array}{c}\text { High } \\
\text { High } \\
\text { High } \\
\text { High } \\
\text { Moderate } \\
\text { Moderate } \\
\text { High } \\
\text { Moderate }\end{array}$ \\
\hline Socio-Economic problems & $\begin{array}{c}\text { Poverty } \\
\text { Unemployment } \\
\text { Community-oil company } \\
\text { Conflict } \\
\text { Intra community conflict } \\
\text { Inadequate compensation } \\
\text { Displacement } \\
\text { Decay in societal values } \\
\text { Poor transportation/high } \\
\text { Cost of fuel } \\
\text { Housing } \\
\text { Pressure/infrastructure } \\
\text { Decay/crime }\end{array}$ & $\begin{array}{l}\text { High } \\
\text { High } \\
\text { High } \\
\text { Moderate } \\
\text { High } \\
\text { Moderate } \\
\text { High } \\
\\
\text { High } \\
\text { High }\end{array}$ \\
\hline
\end{tabular}

Source: NDES 1997 cited in Maduka (1998: 887) \& Okoh and Egbon (1999: 413). 
Table 2. Population size and statutory revenue allocation by states

\begin{tabular}{|c|c|c|}
\hline States & $\begin{array}{c}\text { Average revenue for the period } \\
1990-1996 \text { ( million) }\end{array}$ & Population " 000 " \\
\hline Abia & 645.9 & 2298.0 \\
\hline Adamawa & 614.2 & 2124.1 \\
\hline Akwa-Ibom & 860.6 & 2359.7 \\
\hline Anambra & 711.6 & 2767.9 \\
\hline Bayelsa & 274.4 & NA \\
\hline Bauchi & 891.6 & 4292 \\
\hline Benue & 804.2 & 2780.4 \\
\hline Borno & 878.9 & 2596.6 \\
\hline Cross-River & 583.9 & 1863.6 \\
\hline Delta & 713.9 & 2570.2 \\
\hline Ebony & 315.3 & NA \\
\hline Edo & 698.4 & 2159.9 \\
\hline Ekiti & 302.4 & NA \\
\hline Enugu & 725.7 & 3161.3 \\
\hline Gombe & 335 & NA \\
\hline Imo & 815 & 2485.5 \\
\hline Jigawa & 797.0 & 2829.9 \\
\hline Kaduna & 780.4 & 3969.3 \\
\hline Kano & 3066.4 & 5632.0 \\
\hline Katsina & 826.9 & 3878.8 \\
\hline Kebbi & 667 & 2062.2 \\
\hline Kogi & 715.3 & 2099.1 \\
\hline Kwara & 685.2 & 1566.5 \\
\hline Lagos & 904.9 & 5685.8 \\
\hline Nassarawa & 322.4 & NA \\
\hline Niger & 727.3 & 2482.4 \\
\hline Ogun & 752.0 & 2338.6 \\
\hline Ondo & 840.9 & 3884.5 \\
\hline Osun & 617.2 & 2203.0 \\
\hline Oyo & 869.4 & 3488.8 \\
\hline Plateau & 837.5 & 3283.7 \\
\hline Rivers & 848.6 & 3983.9 \\
\hline Sokoto & 976.8 & 4392.4 \\
\hline Taraba & 663.5 & 1480.6 \\
\hline Yobe & 745.2 & 141.5 \\
\hline Zamfara & 358.5 & NA \\
\hline FCT, Abuja & 907.7 & 378.7 \\
\hline
\end{tabular}

Note: NA means not available.

Source: CBN, 1996 Annual Report;

CBN, 1996 Statistical Bulletin. 
Table 3. Quarterly rural unemployment rates by all Nigeria and States, September, 1993 to June 1995

\begin{tabular}{|c|c|c|c|c|c|c|c|c|}
\hline & Sept. & Dec. & Mar. & June. & Sept. & Dec. & Mar. & June. \\
\hline All Nigeria States & 4.1 & 3.8 & 2.9 & 2.5 & 3.5 & 3.3 & 3.1 & 3.6 \\
\hline Abuja & NA & NA & NA & NA & $\mathrm{NA}$ & NA & NA & NA \\
\hline Akwa-Ibom & 2.8 & 2.2 & 2.9 & NA & $*$ & 2.6 & 3.9 & 4.0 \\
\hline Anambra/Enugu & 1.6 & 5.3 & 2.6 & 3.4 & 8.4 & 3.1 & 4.2 & 4.0 \\
\hline Bauchi & 6.6 & 5.3 & 3.7 & 0.7 & 0.4 & 13.0 & 6.9 & $*$ \\
\hline Edo/Delta & 4.1 & 10.4 & 3.3 & 6.3 & 8.1 & $*$ & 2.8 & 4.1 \\
\hline Borno/Yobe & 8.5 & 1.9 & 3.7 & 1.7 & 5.2 & 0.5 & $*$ & $*$ \\
\hline Cross River & 14.9 & 1.1 & 12.1 & 2.0 & 7.0 & 5.7 & 7.5 & 10.9 \\
\hline Adamawa/Taraba & * & 3.5 & 6.0 & $*$ & 8.1 & 20.0 & 3.0 & 11.7 \\
\hline Imo/Abia & 7.0 & 4.3 & 2.9 & 2.3 & 5.6 & $*$ & 6.3 & 0.7 \\
\hline Kaduna & 4.4 & 6.1 & 0.8 & 2.0 & $*$ & 22.6 & $*$ & 1.3 \\
\hline Kano/Jigawa & 0.6 & 1.1 & 1.7 & 3.7 & $*$ & $*$ & $*$ & 2.5 \\
\hline Katsina & $*$ & 4.7 & 0.8 & $*$ & $*$ & * & 18.4 & $*$ \\
\hline Kwara/Kogi & 7.3 & 1.0 & 1.9 & 3.1 & 0.6 & $*$ & 0.4 & 4.2 \\
\hline Lagos & 1.8 & 3.1 & 2.5 & 1.8 & 2.4 & $*$ & 2.4 & 4.2 \\
\hline Niger & $*$ & 11.1 & 1.8 & 6.8 & 6.1 & * & $*$ & 6.0 \\
\hline Ogun & 2.4 & 2.8 & 1.5 & 1.3 & 1.9 & $*$ & 2.1 & 2.8 \\
\hline Ondo & 5.5 & 2.0 & 0.6 & $*$ & $*$ & 4.5 & 3.3 & 1.9 \\
\hline Oyo/osun & 0.4 & 2.3 & 0.9 & $*$ & 0.7 & 1.4 & 0.9 & 1.8 \\
\hline plateau & 3.0 & 7.3 & 2.6 & 4.8 & 1.0 & 20.8 & 12.6 & 6.7 \\
\hline Rivers & 10.6 & 8.6 & 15.2 & 2.8 & 13.2 & 3.1 & 14.5 & 9.0 \\
\hline Sokoto/kebbi & 1.6 & 1.0 & NA & $*$ & * & * & 1.5 & 2.9 \\
\hline
\end{tabular}

Note: * means less than 0.1 ;

NA means not applicable.

Source: Federal Office of Statistics, Lagos. 
Table 4. Nigeria participating poverty assessment exercise

\begin{tabular}{|c|c|c|c|c|c|}
\hline Year & Real per capita income & Year & Real per capita income & Year & Real per capita income \\
\hline 1971 & 1350 & 1979 & 2300 & 1987 & 1250 \\
\hline 1972 & 1300 & 1980 & 2900 & 1988 & 1200 \\
\hline 1973 & 1450 & 1981 & 2500 & 1989 & 1400 \\
\hline 1974 & 2000 & 1982 & 2000 & 1990 & 1500 \\
\hline 1975 & 1800 & 1983 & 1700 & 1991 & 1480 \\
\hline 1976 & 1850 & 1984 & 1650 & 1992 & 1470 \\
\hline 1977 & 2500 & 1985 & 1750 & 1993 & 1450 \\
\hline 1978 & 2150 & 1986 & 1300 & 1994 & 1400 \\
\hline
\end{tabular}

Source: World Bank (1996). 